\title{
Psychosocial employability attributes as predictors of staff satisfaction with retention factors
}

\author{
Melinde Coetzee, Rudolf M Oosthuizen and Elleen Stoltz
}

\begin{abstract}
The increased mobility of highly skilled knowledge workers who place a high premium on their employability capital challenges organisations to retain their scarce talent. This article explored individuals' psychosocial employability attributes as predictors of their satisfaction with organizational retention factors. A cross-sectional quantitative, correlational research design was followed. A non-probability purposive sample of 321 permanently employed employees in an automotive manufacturing company in South Africa participated in the study $(50 \%$ mid-career; $72 \%$ males; $50 \%$ Blacks; and $79 \%$ managerial/supervisory levels). Hierarchical regression analysis revealed that proactivity positively predicted satisfaction with job characteristics; career self- management positively predicted satisfaction with training and development opportunities, career opportunities, and work-life balance. Emotional literacy negatively predicted satisfaction with career opportunities. The results provide valuable insights regarding how employees' psychosocial employability attributes influence their retention.
\end{abstract}

\section{Keywords}

Career satisfaction, psychosocial employability attributes, retention factors, retention practices

Workforce trends point to a current and future scarcity of highly skilled employees with the essential knowledge and capability to perform at high levels (Department of Higher Education, 2014; Stoltz, 2015). Keeping employees committed to the organisation and retaining their valuable skills has therefore become a top priority for many contemporary organisations (Neininger, Lehmann- Willenbrock, Kauffeld, \& Henschel, 2010; Stoltz, 2015). The retention of valuable knowledge and experience is an important contributor to an organisation's sustainability and competitiveness (Burke \& Ng, 2006; Department of Higher Education, 2014; Mohlala, Goldman, \& Goosen, 2012; Olckers \& Du Plessis, 2012), a fact which has resulted in skilled, engaged, and committed employees being characterised as the principal differentiating factor for most 21st century organisations (Samuel \& Chipunza, 2009; Veldsman \& Coetzee, 2014). The global skills shortages require managers, industrial psychologists, and human resources practitioners to not only understand the reasons why people leave their organisations, but also the factors that influence the turnover and retention of employees. By understanding the reasons why people leave and the factors that influence turnover and retention, psychologists and practitioners can contribute positively to the design of organisational retention practices (Stoltz, 2015; Van Dyk \& Coetzee, 2012). 
Research has shown, for example, that organisational concerns about the retention of employees are intensified by the mobility of highly skilled individuals who place a high premium on their employability capital (Mashilo, 2010; Stoltz, 2015). Individuals' employability capital comprises their human capital (qualifications, work and life experience, work-related skills, and marketability) and psychosocial career capital (Fugate, Kinicki, \& Ashforth, 2004; Haines, Mamouche, \& Saba, 2014; Maurer \& Chapman, 2013), the latter referring to individuals' psycho- social resources and employability attributes (career meta-capacities) which facilitate proactive career management behaviours (Coetzee, 2014; Potgieter, 2014).

Psychosocial career capital has been shown to relate to individuals' subjective work experiences and job and career satisfaction (Coetzee \& Bergh, 2009). However, it is unclear from the research literature how individuals' psychosocial career capital relates to their satisfaction with human resource practices that are considered to be important for retaining staff (Döckel, 2003; Döckel, Basson, \& Coetzee, 2006). This article contributes to the discipline of psychology by exploring how individuals' psychosocial employability attributes (as aspects of their psychological career capital) relate to their subjective experiences of key organisational retention practices or factors (i.e., compensation, job characteristics, training and development, supervisor support, career opportunities, and work-life balance).

\section{The relationship between psychosocial employability attributes and retention factors}

The constructs of psychosocial employability attributes and retention factors are studied within the context of post-modern life design theory. The psychology of life designing advances a contextualist epistemology that emphasises uniqueness in human diversity and purposiveness in work and career to construct a life of personal meaning and social consequence (Hartung, 2013). Individuals' careers are embedded within specific sociocultural and environmental contexts and the characteristics, demands, and expectations posed by these contexts influence individuals' perceptions of their career success and satisfaction (Savickas, 2013). Career management and development is seen as an intentional life-long process of adapting to ever-changing variables in the contexts within which the career is constructed (Di Fabio \& Maree, 2013). Adaptation is focused on shaping the self and career through work and relationships, and optimising self-environment congruency by the intentional use of inner or personal self-regulatory resources (Hartung, 2013; Savickas \& Porfeli, 2012). In this study, psychosocial employability attributes represent selfregulatory personal resources while retention factors represent characteristics of the socio-environmental context within which the career is constructed (Stoltz, 2015). Employability attributes are a set of outlooks and intrinsic self-regulatory abilities or personal resources that predispose an individual to specific behaviours which include the cognitive adjustment of goals and behaviours in order to enhance personenvironment alignment (Botha, 2014; Lent, 2013). 
As a psychosocial construct, employability attributes explain proactive career management behaviour in changing environments and the career-related attributes and skills (meta- capacities) individuals employ to enhance their suitability for appropriate and sustainable employment (Bezuidenhout, 2011; Potgieter, 2014). Bezuidenhout (2011) differentiates between eight core employability attributes which are regarded as vital for increasing an individual's employability:

$>$ Career self-management. The ability to sustain employability through continuous learning, career planning, and management efforts;

$>$ Cultural competence. The ability to understand, act, and interface successfully with a diverse cultural environment;

$>$ Self-efficacy. The estimate an individual makes of his or her ability to cope, perform, and thrive;

$>$ Career resilience. A disposition that facilitates a high level of adaptation, selfconfidence, competence, and confidence;

$>$ Sociability. The ability to be open to, establish, and maintain social contacts, including using formal and informal networks for the benefit of one's career;

$>$ Entrepreneurial orientation. Being open for innovation and creativity, taking risks, a need for achievement, a tolerance for uncertainty and autonomy in the exploitation of opportunities within the career environment;

$>$ Proactivity. The tendency to engage in active role orientations that lead to future-oriented and self-initiated action in order to adapt to changing circumstance;

$>$ Emotional literacy. The ability to use emotions adaptively, and to read, understand, and control one's own and others' emotions.

These psychosocial employability attributes have been related to self-directed behaviour (Botha, 2014), personal initiative and openness to change (Van Dam, 2004), career satisfaction (Coetzee \& Beukes, 2010), and individuals' career motives and interests (Oosthuizen, Coetzee, \& Mntonintshi, 2014). The attributes are also seen to promote adaptive cognition, behaviour, and affect (Bezuidenhout, 2011). Retention factors are those organisational practices that influence the retention or departure of employees and their decision to leave or remain (Döckel et al., 2006; Netswera, Rankhumise, \& Mavundla, 2005). Döckel (2003) identified six factors critical to the retention of employees in the South African organisational context:

$>$ Compensation. Competitiveness of salary package, value of benefits, and organisational remuneration policies;

$>$ Job characteristics. Independence and freedom, task variety; use of personal initiative, and use of complex or high level skills;

$>$ Training and development opportunities. Job-specific training, product and solution training, opportunity for professional growth and development, workplace application of learning;

> Supervisor support. Positive feedback on performance, praise and recognition, reward and acknowledgement for work well done;

$>$ Career opportunities. Advancement and individual career development opportunities within the organisation; and

$>$ Work-life balance. Perception of harmony or conflict between the work and life (personal) domain. 
These factors have been positively related to employee turnover, job embeddedness, job and career satisfaction, engagement, and commitment (Döckel, 2003; Du Toit \& Coetzee, 2012; Joāo \& Coetzee, 2012; Ng \& Feldman, 2009; Van Dyk, Coetzee, \& Takawira, 2013). Research high- lights the interdependency between individuals and the structural arrangements and practices of organisations (Fleisher, Khapova, \& Jansen, 2014; Tams \& Arthur, 2010). Organisational business needs for success are achieved through addressing employees' career satisfaction and by balancing business needs with employees' subjective and objective career needs and goals (Fleisher et al., 2014; Lips-Wiersma \& Hall, 2007). Organisational retention factors or practices represent certain characteristics of the structure within which the career is pursued and that relate to measures of individuals' career success or satisfaction (Döckel et al., 2006; Van Dyk \& Coetzee, 2012). In this regard, individuals' psychosocial employability attributes function as the self- regulatory meta-capacities or resources employed to facilitate person-structural alignment in order to enhance experiences of career success and satisfaction (Ferreira, 2014; Savickas \& Porfeli, 2012; Zacher, 2014).

It is evident from the research literature that individuals' psychosocial employability attributes and their satisfaction with retention factors are associated with their subjective career experiences. This study may potentially add valuable new insights to the career and retention literature by investigating the association between individuals' psychosocial employability attributes and their satisfaction with key organisational retention factors. To date, there seems to be a paucity regarding research on the relationship between these variables. The research question pertaining to this study was as follows: Do individuals' psychosocial employability attributes significantly and positively predict their satisfaction with the retention factors identified by Döckel (2003)? Based on the research literature, it was expected that individuals' psychosocial employability attributes would positively influence their level of satisfaction with the six retention factors.

\section{Method}

\section{Participants}

A non-probability purposive sample of 321 employees from a population of staff and managerial level employees who were permanently employed in an automotive manufacturing company in South Africa participated in the study. The participants were mostly in the early career stage (20-39 years: 48\%) and mid-career stage (40-59 years: $50 \%$ ). The sample was skewed towards males $(72 \%)$ with an equal representation of White (50\%) and Black (50\%) participants. The majority of the participants have been in the company's employment for less than 5 years (36\%) and more than 6 years $(64 \%)$. The participants occupied positions on a managerial/supervisory level (79 \%) and operational level (21\%).

\section{Measuring instruments}

Psychosocial employability attributes were measured by means of the Employability Attributes Scale (EAS). The EAS (Bezuidenhout \& Coetzee, 2010) is a self-rated, multifactorial measure which contains 56 items and eight sub-scales: career self- 
management (11 items; e.g., 'I know what I must do to make a success of my career'), career resilience (6 items; e.g., "I anticipate and take advantage of changes in my career environment'), entrepreneurial orientation (7 items; e.g., 'I continuously look into new business opportunities'), proactivity (7 items; e.g., 'I spend a lot of time enhancing my knowledge and skills to benefit my career), self-efficacy (6 items; e.g., 'When I achieve something, it is because of my own effort'), emotional literacy (7 items; e.g., 'I can easily understand why I feel a certain way'), sociability (7 items; e.g., 'I can use my networks to find new job opportunities'), and cultural competence (5 items; e.g., "I can easily initiate and maintain relationships with people from different cultures). Respondents were required to rate each item on a six-point Likert-type scale $(1=$ never true for me; $6=$ always true for me). The EAS has proven reliability and validity in the South African context (Oosthuizen et al., 2014; Potgieter \& Coetzee, 2013). Acceptable internal consistency reliability coefficients (Cronbach's alpha) ranging between .71 (self-efficacy) and .91 (cultural competency) were obtained for this study.

Retention factors were measured using the Retention Factor Scale (RFS) which was developed by Döckel (2003). The RFS measures the participants' satisfaction with the following six retention factors on a six-point Likert-type scale $(1=$ strongly dissatisfied; 6 = strongly satisfied): compensation (13 items, e.g., ' On my present job this is how I feel about my benefits package'), job characteristics (4 items, e.g., 'The job requires me to use a number of complex or high-level skills'), training and development opportunities (6 items, e.g., 'The company is providing me with jobspecific training'), supervisor support (6 items, e.g., 'My supervisor looks for opportunities to praise positive employee performance, both privately and in front of others'), career opportunities (6 items, e.g., 'My chances for being promoted are good), and work-life balance (4 items, e.g., 'I often feel like there is too much work to do'). The RFS has proven reliability and validity in the South African context (Döckel et al., 2006; Van Dyk et al., 2013). Acceptable internal consistency reliability coefficients (Cronbach's alpha) ranging between .60 (job characteristics) and .96 (compensation) were obtained for this study. Demographic data were obtained from the participants by means of a biographical questionnaire. The demographic data included: age (coded $0=\leqslant 45$ years; $1=\geqslant 46$ years), gender (coded $0=$ male; $1=$ female), race (coded $0=$ Black; $1=$ White), and job level (coded $0=$ managerial/supervisory level; $1=$ operational level staff). These variables served as control variables in the statistical analyses in order to increase the validity of our results and to avoid confounding variables. The demographic variables included in the study were all shown to be related to individuals' retention (Stoltz, 2015).

\section{Procedure}

A cross-sectional, quantitative research approach was followed to achieve the research objective. Data were collected through questionnaires administered during working hours in individual and group sessions. Five hundred and twenty-eight (528) questionnaires were distributed and 321 questionnaires with complete data were returned, yielding a response rate of 61 per cent. 


\section{Ethical considerations}

Ethical clearance to conduct the study was obtained from the Research Ethics Committee of the research institution. Permission for the research was obtained from the human resource director of the company. The participants were invited to voluntarily participate and sign an informed consent form. The privacy, anonymity, and confidentiality of all the participants were ensured and honoured.

\section{Statistical analyses}

Correlational statistics were calculated to determine the direction and strength of the relationship between the variables. In order to counter the probability of a Type I error, the significance value for the interpretation of correlations was set at the $95 \%$ confidence interval level $(p \leqslant .05)$. Hierarchical multiple regressions were performed to explore the proportion of variance in the dependent variables (retention factors' satisfaction variables) that was explained by the independent variables (psychosocial employability attributes and biographical variables). The variables were entered in two blocks; in the first stage, the demographic variables were entered as a block of control variables and in the second stage, the EAS variables were entered as a block of variables. As per the guidelines of Tabachnick and Fidell (2007), this approach assisted in controlling for the effect of the demographic variables in the analysis of the predictive validity of the EAS variables. Prior to conducting the various regression analyses, collinearity diagnostics (variance inflation factor and tolerance values) were examined to assess the probability of multicollinearity. The regression models revealed that the variance inflation factors were all below 5.0 (thus not exceeding the threshold value of 10.00 for multicollinearity concerns). The tolerance values were below .40 and thus not close to 1.0 (sign of multicollinearity) as per the guidelines of Field (2009). Because multiple tests were conducted (6 regression models), a Bonferroni correction was also calculated by adjusting the $p$-value to $\alpha / k(.05 / 6=.008)$. The adjusted $p$-value for interpreting the significance of the six regression models was therefore set at $p \leqslant$ .008 in order to counter for Type I error. In addition, Cohen's (1992) effect sizes were calculated for establishing the practical significance of the $R^{2}$ and $\Delta R^{2}$.

\section{Results}

\section{Descriptive statistics}

The means, standard deviations, internal consistency reliabilities, and bivariate correlations are reported in Table 1. As shown in Table 1, the practical effect of the significant inter-correlations among the EAS variables ranged between $r \geqslant .42 \leqslant .83$ (moderate to large effect; $p \leqslant .001$ ) and among the RFS variables between $r \geqslant .12 \leqslant$ .53 (small to large effect; $p \leqslant .001$ ). The significant inter-correlations among the EAS and RFS variables were also small in practical effect $(r \geqslant .12 \leqslant .31 ; p \leqslant .05)$. The correlation results confirm no multicollinearity concerns in terms of interpreting the regression analysis results. With the exception of race and job level, the other associations between age and gender and the EAS and RFS variables were regarded as negligible. 


\section{Regression analysis}

Table 2 provides the summary of results from the hierarchical multiple regression analyses, with the biographical variables and psychosocial employability attributes as the independent variables and retention factors as the dependent variables. Six models were extracted (one model for each of the RFS variables) of which four were significant, namely, job characteristics $\left(R^{2}=.15 ; p=.000\right.$; medium practical effect), training and development opportunities $\left(R^{2}=.11 ; p=.005\right.$; small practical effect), career opportunities ( $R^{2}=.16 ; p=.000$; medium practical effect), and work-life balance $\left(R^{2}=.12 ; p=.001\right.$; small practical effect). The significance level of these four regression models were all below the Bonferroni-adjusted level of $p \leqslant .008$. Table 2 shows that proactivity contributed the most in explaining the variance in job characteristics $\left(\beta=.52 ; p \leqslant .001 ; s t^{2}=.27\right.$; large practical effect in terms of incremental variance explained). Career self-management contributed the most in explaining the variance in training and development $\left(\beta=.35 ; p \leqslant .01 ; s r^{2}=.12\right.$; moderate practical effect in terms of incremental variance explained), career opportunities $\left(\beta=.44 ; p \leqslant .001 ; s r^{2}=.19\right.$; moderate practical effect in terms of incremental variance explained), and work-life balance $\left(\beta=.24 ; p \leqslant .05 ; s r^{2}=.06\right.$; small practical effect in terms of incremental variance explained). Emotional literacy contributed negatively towards explaining the variance in career opportunities $(\beta=$ $-.22 ; p \leqslant .05 ; s r^{2}=.05$; small practical effect in terms of incremental variance explained).Table 2 shows that job level contributed significantly towards explaining the variance in job characteristics $\left(\beta=-.14 ; p \leqslant .05 ; s r^{2}=.02\right)$ and training and development opportunities $\left(\beta=.17 ; p \leqslant .01 ; s r^{2}=.03\right)$. However, the contribution was small in practical effect in terms of incremental variance explained. Similarly, although race negatively and significantly contributed towards explaining work-life balance $\left(\beta=-.18 ; p \leqslant .05 ; s r^{2}=.03\right)$, the results showed that only a small practical effect in terms of incremental variance was explained. 
Table I. Descriptive statistics: biographical, psychosocial employability attributes, and retention factor variables.

\begin{tabular}{|c|c|c|c|c|c|c|c|c|c|c|c|c|c|c|c|c|c|c|c|c|c|c|}
\hline \multicolumn{2}{|c|}{ Variable } & \multirow{2}{*}{$\frac{\alpha}{n / a}$} & \multirow{2}{*}{$\frac{M}{.41}$} & & \multirow[t]{2}{*}{2} & \multirow[t]{2}{*}{3} & \multirow[t]{2}{*}{4} & \multirow[t]{2}{*}{5} & \multirow[t]{2}{*}{6} & \multirow[t]{2}{*}{7} & \multirow[t]{2}{*}{8} & \multirow[t]{2}{*}{9} & \multirow[t]{2}{*}{10} & \multirow[t]{2}{*}{11} & \multirow[t]{2}{*}{12} & \multirow[t]{2}{*}{13} & \multirow[t]{2}{*}{14} & \multirow[t]{2}{*}{15} & \multirow[t]{2}{*}{16} & \multirow[t]{2}{*}{17} & \multirow[t]{2}{*}{18} & \multirow[t]{2}{*}{19} \\
\hline 1 & Age & & & .491 .00 & & & & & & & & & & & & & & & & & & \\
\hline 2 & Gender & $\mathrm{n} / \mathrm{a}$ & .27 & $.45-.05$ & 1.00 & & & & & & & & & & & & & & & & & \\
\hline 3 & Race & $\mathrm{n} / \mathrm{a}$ & .59 & $.49 .22^{* \star *}$ & -.08 & 1.00 & & & & & & & & & & & & & & & & \\
\hline 4 & Tenure & $\mathrm{n} / \mathrm{a}$ & .14 & $.34 .48^{\star \star \star}$ & $-.10^{*}$ & * $.15^{\star *}$ & 1.00 & & & & & & & & & & & & & & & \\
\hline 5 & Job level & $\mathrm{n} / \mathrm{a}$ & .22 & $.42-.27^{\star \star \star}$ & .10 & $-.34^{\star \star \star}$ & $\star-.19^{\star \star \star}$ & * 1.00 & & & & & & & & & & & & & & \\
\hline 6 & Career self-management & .89 & 4.56 & $.72-.09$ & -.03 & $-.46^{\star * *}$ & ${ }^{*}-.12^{*}$ & $.29^{* * *}$ & $* 1.00$ & & & & & & & & & & & & & \\
\hline 7 & Cultural competence & .91 & 4.40 & $.90 \quad .00$ & .01 & $-.32^{* * *}$ & -.03 & $.15^{\star \star}$ & $.55^{\star \star *}$ & 1.00 & & & & & & & & & & & & \\
\hline 8 & Self-efficacy & .71 & 4.69 & $.64-.08$ & .00 & $-.27^{\star * *}$ & $-.15^{\star \star}$ & $.19^{\star \star \star}$ & $.66^{\star \star \star}$ & $.42^{\star \star \star}$ & * 1.00 & & & & & & & & & & & \\
\hline 9 & Career resilience & .79 & 4.49 & $.69-.11^{*}$ & -.04 & $-.37^{\star \star \star}$ & ${ }^{\star}-.15^{\star}$ & $.21^{\star * *}$ & $.72^{\star \star *}$ & $.63^{\star \star *}$ & * $.64^{* * *}$ & 1.00 & & & & & & & & & & \\
\hline 10 & Sociability & .77 & 4.21 & $.74-.06$ & .02 & $-.42^{\star * *}$ & -.11 & $.25^{\star \star \star}$ & $.69^{\star \star *}$ & $.69^{\star \star \star}$ & * $.54^{\star \star *}$ & $.69^{* * *}$ & 1.00 & & & & & & & & & \\
\hline 11 & Entrepreneurial orientation & .80 & 4.66 & $.66-.05$ & -.08 & $-.31^{* * *}$ & $-.13^{*}$ & $.26^{\star \star \star}$ & $.78^{* * *}$ & $.55^{\star \star *}$ & * $.71^{* \star *}$ & $.75^{\star * *}$ & $.66^{* \star *}$ & * 1.00 & & & & & & & & \\
\hline 12 & Proactivity & .85 & 5.67 & $.68-.02$ & -.07 & $-.29^{\star * *}$ & -.08 & $.17^{\star \star}$ & $.79^{\star \star \star}$ & $.62^{\star \star *}$ & * $.68^{* * *}$ & $.80^{\star * *}$ & $.69^{\star \star \star}$ & ${ }^{*} .83^{\star * *}$ & 1.00 & & & & & & & \\
\hline 13 & Emotional literacy & .86 & 4.50 & $.76 \quad .08$ & .00 & $-.24^{\star * *}$ & -.03 & $.14^{*}$ & $.58^{\star * *}$ & $.55^{\star \star *}$ & * $.57^{* \star *}$ & $.62^{\star * *}$ & $.52^{\star \star \star}$ & * $.58^{* \star *}$ & $.66^{* \star *}$ & 1.00 & & & & & & \\
\hline 14 & Compensation & .96 & 3.64 & $1.16-.02$ & .01 & $.15^{\star *}$ & .08 & -.06 & .00 & -.06 & $-.12^{*}$ & -.07 & -.09 & -.08 & -.06 & -.09 & 1.00 & & & & & \\
\hline 15 & Job characteristics & .60 & 4.49 & $.88 \quad .06$ & -.11 & .10 & -.05 & $-.15^{\star \star}$ & .08 & .02 & .01 & .08 & .05 & .05 & $.16^{\star \star}$ & -.00 & $.28^{\star \star \star}$ & 1.00 & & & & \\
\hline 16 & $\begin{array}{l}\text { Training \& development } \\
\text { opportunities }\end{array}$ & .91 & 3.62 & 1.21 .03 & -.08 & $-.13^{\star}$ & .04 & $.22^{\star \star *}$ & $.24^{\star \star \star}$ & $.15^{\star \star}$ & .06 & $.12^{*}$ & $.14^{\star *}$ & $.15^{\star *}$ & $.13^{*}$ & $.12^{*}$ & $.49^{* * *}$ & $.27^{\star \star \star}$ & 1.00 & & & \\
\hline 17 & Supervisor support & .79 & 4.29 & $1.06-.07$ & -.06 & .02 & -.06 & -.03 & $.16^{\star *}$ & .06 & .02 & $.13^{*}$ & .10 & .10 & $.15^{\star \star}$ & .08 & $.36^{* * *}$ & $.38^{* * *}$ & $.32^{* \star *}$ & 1.00 & & \\
\hline 18 & Career opportunities & .72 & 3.46 & $.96-.16^{\star *}$ & $-.13^{*}$ & ${ }^{*}-.13^{*}$ & $-.12^{*}$ & $.21^{\star \star *}$ & $.31^{* \star *}$ & .09 & .08 & $.18^{\star \star *}$ & $.18^{\star \star \star}$ & * $.18^{\star * *}$ & $.18^{* \star *}$ & .01 & $.46^{\star * *}$ & $.31^{* \star \star}$ & $.53^{\star \star \star}$ & $.39^{* \star *}$ & 1.00 & \\
\hline 19 & Work-life balance & .86 & 3.87 & $1.24 \quad .02$ & -.05 & $-.25^{\star \star *}$ & .06 & $.19^{\star \star \star}$ & $.18^{* \star *}$ & $.12^{*}$ & .03 & $.14^{\star \star}$ & .09 & .10 & .09 & $.15^{* *}$ & $.18^{\star * \star}$ & .06 & $.20^{\star * *}$ & $.24^{\star \star \star}$ & $.26^{\star \star \star}$ & 1.00 \\
\hline
\end{tabular}

$N=321 ;{ }^{* *} p \leqslant .001-$ statistically significant. ${ }^{* *} p \leqslant .01-$ statistically significant. ${ }^{*} p \leqslant .05-$ statistically significant. 
Table 2. Results of the multiple regression analysis: psychosocial employability attributes as predictors of retention factor satisfaction.

\begin{tabular}{|c|c|c|c|c|c|c|c|c|c|c|c|c|}
\hline \multirow[t]{2}{*}{ Predictor variables } & \multicolumn{2}{|c|}{ Compensation } & \multicolumn{2}{|c|}{ Job characteristic } & \multicolumn{2}{|c|}{$\begin{array}{l}\text { Training and } \\
\text { development } \\
\text { opportunities }\end{array}$} & \multicolumn{2}{|c|}{ Supervisor support } & \multicolumn{2}{|c|}{$\begin{array}{l}\text { Career } \\
\text { opportunities }\end{array}$} & \multicolumn{2}{|c|}{ Work-life balance } \\
\hline & $\beta$ & $\begin{array}{l}\text { Semi- } \\
\text { partial } r^{2}\end{array}$ & $\beta$ & $\begin{array}{l}\text { Semi- } \\
\text { partial } r^{2}\end{array}$ & $\beta$ & $\begin{array}{l}\text { Semi- } \\
\text { partial } r^{2}\end{array}$ & $\beta$ & $\begin{array}{l}\text { Semi- } \\
\text { partial } r^{2}\end{array}$ & $\beta$ & $\begin{array}{l}\text { Semi- } \\
\text { partial } r^{2}\end{array}$ & $\beta$ & $\begin{array}{l}\text { Semi- } \\
\text { partial } r^{2}\end{array}$ \\
\hline Age & -.07 & .01 & .12 & .01 & .05 & .00 & -.07 & .01 & -.08 & .01 & .10 & .01 \\
\hline Gender & .06 & .00 & -.08 & .01 & -.06 & .00 & -.01 & .00 & -.07 & .01 & -.01 & .00 \\
\hline Job level & -.02 & .00 & $-.14^{*}$ & .02 & $.17^{* *}$ & .03 & -.08 & .01 & .07 & .01 & .10 & .01 \\
\hline Career self-managemen & $.35^{\star *}$ & .12 & .09 & .01 & $.35 * *$ & .12 & $.28^{*}$ & .08 & $.44 * * *$ & .19 & $.24^{*}$ & .06 \\
\hline Cultural competence & .05 & .00 & -.05 & .00 & .14 & .02 & -.13 & .02 & -.07 & .01 & .02 & .00 \\
\hline Self-efficacy & -.15 & .02 & -.12 & .01 & -.10 & .01 & -.08 & .01 & -.14 & .02 & -.10 & .01 \\
\hline Career resilience & .02 & .00 & .07 & .01 & -.03 & .00 & .04 & .00 & .11 & .01 & .13 & .02 \\
\hline Sociability & -.10 & .01 & .04 & .00 & -.05 & .00 & .10 & .01 & .05 & .00 & -.04 & .00 \\
\hline \multicolumn{13}{|l|}{ Model } \\
\hline$R^{2}$ & .08 & & .15 & & .11 & & .08 & & .16 & & .12 & \\
\hline$\Delta R^{2}$ & .04 & & .10 & & .05 & & .07 & & .10 & & .03 & \\
\hline \multirow[t]{2}{*}{ F(df; mean square) } & 1.70 & & $3.43 * * *$ & & $2.39 * *$ & & 1.66 & & 3.73 & & 2.79 & \\
\hline & $(13 ; 2.30)$ & & $(13 ; 2.33)$ & & $(13 ; 3.21)$ & & $(13 ; 1.83)$ & & $(13 ; 2.9$ & & $(13 ; 3.82)$ & \\
\hline$\Delta F$ & 1.53 & & $3.54 * *$ & & 1.88 & & 2.39 & & $3.75^{\circ}$ & & 1.25 & \\
\hline
\end{tabular}

$N=321 ;{ }^{* * *} p=.000-$ statistically significant. ${ }^{* *} p \leqslant .008-$ statistically significant. ${ }^{*} p \leqslant .05-$ statistically significant. All statistics are from the final step in each model. Standardised beta values are reported. 


\section{Discussion}

This study explored whether individuals' psychosocial employability attributes significantly and positively predict their satisfaction with key organisational retention factors. Overall, the results identified career self-management, proactivity, and emotional literacy as psychosocial employability attributes that influenced the participants' satisfaction with certain retention factors. The study results provided evidence that employees who take responsibility for their career goals and manage their own action plans experience greater satisfaction with training and development opportunities and career opportunities. Bezuidenhout (2011) also associated career self- management with an employee's ability to have clear career aspirations and to recognise the skills needed to achieve career goals, as well as continuous engagement in developmental activities. Previous research has shown that perceived training and development and career opportunities significantly predict job performance and reduce intentions to leave (João, 2010; Kraimer, Seibert, Wayne, Liden, \& Bravo, 2011; Morrow, 2011; Weng, McElroy, Morrow, \& Liu, 2010). Career self- management was also positively associated with higher levels of work-life balance satisfaction. Research by Du Toit and Coetzee (2012) showed that individuals' need for worklife balance is positively associated with their career management behaviours and perceptions of subjective career success.

The results further contribute supportive evidence to the findings of previous researchers regarding the factors that drive the retention of highly specialised knowledge workers. Spector (2008) found that highly specialised knowledge workers, such as the participants from the auto- motive manufacturing company, preferred jobs where they can use a variety of skills and experience challenging assignments and job autonomy. This study's results suggest that employees who take proactive steps towards setting challenging targets, taking accountability for their decisions, and improving their knowledge and skills for career progression are likely to experience their work assignments as interesting, varied, and challenging. Westlund and Hannon (2008) found satisfaction with the nature of work to be significantly related to an employee's intention to leave an organisation. Although small in practical effect, emotional literacy was shown to negatively predict the participants' satisfaction with career opportunities. This study's results suggest that individuals who are in touch with, and able to manage, their own and others' emotions are likely to be dissatisfied with the perceived career growth opportunities offered by the organisation. This finding is contrary to previous research showing that managing own and others' emotions positively influences individuals' inclination to explore their environment for career opportunities and to act with greater confidence in mastering the developmental tasks and challenges associated with one's career (Coetzee \& Harry, 2014). Coetzee and Beukes (2010) also found that higher levels of emotional intelligence lead to greater levels of satisfaction with perceived support in one's career preparation. 


\section{Study limitations and future studies}

Since the current study was restricted to respondents employed in the automotive manufacturing industry, the findings cannot be generalised to other occupational contexts. The cross-sectional nature of the research design limits the possibility of ascertaining the causal direction of relations between the variables. Replication and longitudinal studies using independent samples drawn from other occupational contexts with broader representation of the diverse populations in South African organisations are recommended.

\section{Concluding remarks}

This study added to the research literature on careers and retention by showing that individual' career self-management, proactivity, and emotional literacy significant predict their satisfaction with certain retention factors. The findings may potentially inform organisational retention practices pertaining to these factors. The results of the study point to the importance of developing employees' career self-management and proactivity as part of their career development for retention purposes, and to be aware of how their emotional literacy influences their satisfaction with perceived career opportunities. Organisational career development support initiatives could encourage employees to participate proactively in training and development opportunities as part of their career self-management, while ensuring that formal career discussions provide clarity on future upward and/or lateral career paths within the organisation. Career development discussions could also focus on encouraging employees to be proactive in their career self-management by, for example, setting their own career goals and developing career plans, and to become aware of how their emotional literacy influences their career satisfaction.

\section{Declaration of conflicting interests}

We hereby declare that we have no conflict of interest and that the manuscript has not been submitted else- where for either review or publication.

\section{Funding}

This research received no specific grant from any funding agency in the public, commercial, or non-profit sectors. 


\section{References}

Bezuidenhout, M. (2011). The development and evaluation of a measure of graduate employability in the context of the new world of work (Unpublished master's thesis). University of Pretoria, Pretoria, South Africa.

Bezuidenhout, M., \& Coetzee, M. (2010). Exploratory factor analysis of the Employability Attributes Scale: An initial study (Unpublished research report). University of South Africa, Pretoria, South Africa.

Botha, J. (2014). The relationship between adult learner self-directedness and employability attributes: An open distance learning perspective (Unpublished master's dissertation). University of South Africa, Pretoria, South Africa.

Burke, R. J., \& Ng, E. (2006). The changing nature of work and organizations: Implications for human resource management. Human Resource Management Review, 16, 86-94.

Coetzee, M. (2014). A psychological career resources framework for contemporary career development. In M.

Coetzee (Ed.), Psycho-social career meta-capacities: Dynamics of contemporary career development (pp. 87-122). Dordrecht. The Netherlands: Springer International.

Coetzee, M., \& Bergh, Z. (2009). Psychological career resources and subjective work experiences of working adults: An exploratory study. Southern African Business Review, $13(2), 1-31$.

Coetzee, M., \& Beukes, C. (2010). Employability, emotional intelligence and career preparation support satisfaction among adolescents in the school-to-work transition phase. Journal of Psychology in Africa, 20, 439-446.

Coetzee, M., \& Harry, N. (2014). Emotional intelligence as a predictor of employees' career adaptability. Journal of Vocational Behavior, 84, 90-97.

Cohen, J. (1992). Quantitative methods in psychology: A power primer.

Psychological Bulletin, 112(1), 153-159.

Department of Higher Education. (2014). Government Gazette Notice 380: National Scarce Skills List, Version 20 May 2014. Pretoria, South Africa: Government Printer.

Di Fabio, A., \& Maree, J. G. (2013). Career construction and life design: Heralding a new beginning to career counselling in the 21st century. In A. Di Fabio \& J. G. Maree (Eds.),. The psychology of career counseling: New challenges for a new era (pp. 1-14). New York, NY: Nova Science Publishers, Inc. 
Döckel, A. (2003). The effect of retention factors on organisational commitment: An investigation of high technology employees (Unpublished master's thesis). University of Pretoria, Pretoria, South Africa.

Döckel, A., Basson, J. S., \& Coetzee, M. (2006). The effect of retention factors on organizational commitment: An investigation of high technology employees. $S A$ Journal of Human Resource Management, 4(2), 20-28.

Du Toit, D., \& Coetzee, M. (2012). Exploring the perceived career success of staff in a South African science and engineering company. Journal of Psychology in Africa, 22(1), 96-105.

Ferreira, N. (2014). Career meta-competencies in the retention of employees. In M. Coetzee (Ed.), Psychosocial career meta-capacities: Dynamics of contemporary career development (pp. 175-202). Dordrecht. The Netherlands: Springer International.

Field, A. (2009). Discovering statistics using SPSS. (3rd ed.). Thousand Oaks, CA: SACE.

Fleisher, C., Khapova, S., \& Jansen, P. (2014). Effects of employees' career competencies development on organizations: Does satisfaction matter? Career Development International, 10(6). Retrieved from http://dx.doi.org/10.1108/CDI-122013-0150

Fugate, M., Kinicki, A. J., \& Ashforth, B. E. (2004). Employability: A psycho-social construct, its dimensions, and applications. Journal of Vocational Behavior, 65, 14-38.

Haines, V. Y., Mamouche, S., \& Saba, T. (2014). Career success: Fit or marketability? Career Development International, 19, 779-793.

Hartung, P. J. (2013). Career construction counseling. In A. Di Fabio \& J. G. Maree (Eds.), The psychology of career counseling: New challenges for a new era (pp. 15-28). New York, NY: Nova Science Publishers, Inc.

João, T. F. (2010). The relationship between perceived career mobility, career mobility preference, job satisfaction and organisational commitment (Unpublished master's thesis). University of South Africa, Pretoria.

Joāo, T. F., \& Coetzee, M. (2012). Job retention factors, perceived career mobility and organisational commitment in the South African financial sector. Journal of Psychology in Africa, 22(1), 69-76.

Kraimer, M. L., Seibert, S. E., Wayne, S. J., Liden, R. C., \& Bravo, J. (2011). Antecedents and outcomes of organizational support for development: The critical role of career opportunities. Journal of Applied Psychology, 96, 485-500.

Lent, R. W. (2013). Career-life preparedness: Revisiting career planning and adjustment in the new workplace. The Career Development Quarterly, 61, 2-14. 
Lips-Wiersma, M., \& Hall, D. T. (2007). Organizational career development is not dead: A case study on managing the new career during organizational change. Journal of Organizational Behavior, 28, 771-792.

Mashilo, A. M. (2010). Changes in work and production organisation in the automotive industry value chain: An evaluation of the responses by labour in South Africa (Unpublished master's thesis). University of

Witwatersrand, Johannesburg, South Africa.

Maurer, T. J., \& Chapman, E. F. (2013). Ten years of career success in relation to individual and situational variables from the employee development literature. Journal of Vocational Behavior, 83, 450-465.

Mohlala, J., Goldman, G. A., \& Goosen, X. (2012). Employee retention within the Information Technology Division of a South African Bank. South African Journal of Human Resource Management, 10(2), 1-11. doi:10.4102/sajhrm.v10i2.438

Morrow, P. C. (2011). Managing organizational commitment: Insights from longitudinal research. Journal of Vocational Behavior, 79, 18-35.

Neininger, A., Lehmann-Willenbrock, N., Kauffeld, S., \& Henschel, A. (2010). Effects of team and organizational commitment: A longitudinal study. Journal of Vocational Behavior, 76, 567-579.

Netswera, F. G., Rankhumise, E. M., \& Mavundla, T. R. (2005). Employee retention factors for South African higher education institutions: A case study. South African Journal of Human Resource Management, 3(2), 36-40.

Ng, T. W. H., \& Feldman, D. C. (2009). Occupational embeddedness and job performance. Journal of Organizational Behavior, 30, 863-891. Doi: 10.1002/ job.580

Olckers, C., \& Du Plessis, Y. (2012). The role of psychological ownership in retaining talent: A systematic literature review. South African Journal of Human Resource Management, 10(2), 1-18. Doi: 10.4102/ sajhrm.v10i2.415

Oosthuizen, R. M., Coetzee, M., \& Mntonintshi, F. (2014). Investigating the relationship between employees' career anchors and their psychosocial employability attributes in a financial company. South African Journal of Human Resource Management, 12(1), Article \#650. Retrieved from http://dx.doi. org/10.4102/sajhrm.v12i1.650

Potgieter, I. L. (2014). Personality and psycho-social employability attributes as metacapacities for sustained employability. In M. Coetzee (Ed.), Psycho-social career metacapacities: Dynamics of contemporary career development (pp. 35-54).Dordrecht. The Netherlands: Springer International. 
Potgieter, I. L., \& Coetzee, M. (2013). Employability attributes and personality preferences of postgraduate business management students. South African Journal of Industrial Psychology, 39(1), Article \#1064. Retrieved from http://dx.doi.org/10.4102/sajip.v39i1.1064

Samuel, M., \& Chipunza, C. (2009). Employee retention and turnover: Using motivational variables as a panacea. African Journal of Business Management, 3, 410415.

Savickas, M. L. (2013). Career construction theory and practice. In R. W. Lent \& S. D. Brown (Eds.), Career development and counseling: Putting theory and research to work (2nd ed., pp. 147-183). Hoboken, NJ: John Wiley \& Sons.

Savickas, M. L., \& Porfeli, E. J. (2012). Career adapt-abilities scale: Construction, reliability, and measurement equivalence across 13 countries. Journal of Vocational Behavior, 80, 661-673.

Spector, P. E. (2008). Industrial and organisational psychology behaviour (5th ed.). Hoboken, NJ: John Wiley \& Sons.

Stoltz, E. (2015). Employability attributes and career adaptability as predictors of staff satisfaction with retention factors (Unpublished master's dissertation). University of South Africa, Pretoria.

Tabachnick, B. G., \& Fidell, L. S. (2007). Using multivariate statistics. Boston, MA: Pearson International.

Tams, S., \& Arthur, M. B. (2010). New directions for boundaryless careers: Agency and interdependence in a changing world. Journal of Organizational Behavior, 31, 629646.

Van Dam, K. (2004). Antecedents and consequences of employability orientation. European Journal of Work and Organizational Psychology, 131, $29-51$.

Van Dyk, J., \& Coetzee, M. (2012). Retention factors in relation to organisational commitment in medical and information technology services. SA Journal of Human Resource Management, 10(2), 1-11. doi:10.4102/sajhrm.v10i2.433

Van Dyk, J., Coetzee, M., \& Takawira, N. (2013). Satisfaction with retention factors as predictors of the job embeddedness of medical and Information Technology services staff. Southern African Business Review, 17(1), 57-75.

Veldsman, D., \& Coetzee, M. (2014). People performance enablers in relation to employees' psychological attachment to the organization. Journal of Psychology in Africa, 24, 480-486. 
Weng, Q., McElroy, J. C., Morrow, P. C., \& Liu, R. (2010). The relationship between career growth and organizational commitment. Journal of Vocational Behavior, 77, 391-400.

Westlund, S., \& Hannon, J. (2008). Retaining talent: Assessing job satisfaction facets most significantly related to software developer turnover intentions. Journal of Information Technology Management, 19(4), 1-15.

Zacher, H. (2014). Individual difference predictors of change in career adaptability over time. Journal of Vocational Behavior, 84, 188-198. 